\title{
Yabancı Dil Olarak Türkçe Öğretiminde Metin Değiştirimine Ömer Seyfettin'in "Rüşvet" Hikâyesi Örneği
}

\author{
Şeyma KÖKCÜ*
}

\begin{abstract}
$\ddot{O} z$
İletişimin temel birimi olan metinler yabancı dil öğretiminde de önemli bir role sahiptir. Hedef dilin birinci dil konuşurları tarafından nasıl kullanıldığını yansıtması, hedef dile ait kültürel ögeleri ve edimbilimsel yapıları içermesi bakımından özgün metinler yabancı dil öğretiminde yaygın şekilde kullanılmaktadır. Bununla birlikte, özgün metnin öğrenicilerin düzeyine uygun olmadı̆̆ durumlar olmakta ve bu durumda özgün metin, çeşitli değiştirim işlemleriyle öğrenicilerin düzeyine uygun hâle getirilmektedir. Bu işlemler, çoğunlukla sezgisel olarak yapılmasına rağmen metin seçiminden değiştirime kadar göz önünde bulundurulması gereken ilkeler bulunmaktadır. Bu bağlamda, bu çalışmada öncelikle metnin dilbilgisel ve içeriksel özellikleri kapsamında söz konusu ilkeler belirlenmeye çalışılmıştır. Daha sonra, bu ilkelere dayanarak B1 düzeyine göre yabancı dil olarak Türkçe öğrenen öğrenciler için metin değiştirimi hedeflenmiştir. Değiştirim için Ömer Seyfettin'in 'Rüşvet' adlı hikâyesi kullanılmıştır. Hikâye, kurmaca anlatı metni olması sebebiyle öğrencilerde heyecan uyandıracă̆ ve evrensel retorik şemayla metnin yapısının daha kolay anlaşılacağı düşünülerek seçilmişsir. Hikâyenin çözümlemesi yapılarak kelime ve cümle düzeylerinde değiştirim işlemleriyle hikâye B1 düzeyine uygun hâle getirilmiş̧tir.
\end{abstract}

Anahtar Kelimeler: Yabancı Dil Olarak Türkçe Öğretimi, anlatı metinleri, metin seçim ilkeleri, metin değiştirimi

\footnotetext{
* Öğr. Gör., Tokat Gaziosmanpaşa Üniversitesi, Yabancı Diller Yüksekokulu, Tokat, Türkiye. Elmek: seyma.kokcu@gop.edu.tr https://orcid.org/0000-0002-0043-1076
} 


\title{
Text Modification in Teaching Turkish as a Foreign Language: "Rüşvet” by Ömer Seyfettin
}

\begin{abstract}
By enabling the verbal discourse to be permanent in written form, texts play an important role in foreign language teaching. As they reflect cultural components and pragmatic units of the target language (TL) and how the TL is used by native speakers, using authentic texts in teaching foreign languages has been emphasized. On the other hand, the authentic texts may not always fit learners' proficiency level. In such cases, authentic texts are reconstructed according to the learners' needs and proficiency level through some modification. The process of modification is usually carried out intuitively by the teachers. However, some principles should be taken into consideration before choosing a text to modify and while modifying the text. In this respect, this study aims to identify principles of selecting and modifying texts. Then, based on these principles, it was aimed to modify 'Rüşvet', a short story by Ömer Seyfettin, to be used for B1 level Turkish as a foreign language learners. As the story is a fictional narrative text, it was assumed that it would arouse interest in learners and they would comprehend the text easily via the existing rhetorical structure in their minds. To modify the text, it was first analyzed regarding its vocabulary and sentence level structure, and then it was modified accordingly.
\end{abstract}

Keywords: Teaching Turkish as a foreign language, narrative texts, principles of text selection, text modification 


\section{Extended Summary}

This study aimed to identify the principles of text selection and modification in foreign language teaching. Following that, it was aimed to modify an authentic text, 'Rüşvet' by Ömer Seyfettin, to fit B1 level Turkish as a foreign language learners' needs. The rationale behind this study is that texts have a crucial role in foreign language teaching. A text not only improves learners' reading ability, it also presents the cultural aspects of the target language. By reading an authentic text, learners can see how the target language is used in the context by the first language speakers as these texts provide readers with real communication contexts. Thus, besides learning the grammar of the target language, they can also learn the sociocultural aspects of it as well, developing their pragmatic competence. Unlike authentic texts, pedagogic materials which are developed for teaching do not reflect the real use of language. They fail to provide the learners with the appropriate and enough input to develop their knowledge regarding the sociocultural aspects of the language. Therefore, language teachers try to use authentic texts while teaching. However, low proficiency level learners might have problems with coping with authentic texts. In such cases, teachers or material developers modify the authentic texts to fit the students' level by trying to protect the main structure of the text and keeping it a little bit forward from the current situation of the students in relation to comprehensible input theory by Krashen. These modifications can be simplification or elaboration based on the changes conducted in the text. On the other hand, it is seen in the existing studies that the text modifiers usually carry out the changes instinctively. For this reason, this study aimed to suggest some principles to be followed for text modification.

Another important aspect of text modification is the kind of authentic text to be used. Therefore, principles which should be taken into consideration while selecting a text for modification were tried to be identified based on the literature. These principles are related to the lexical items, grammar and content 
of a text. To achieve this, first, the role of a text in foreign language teaching has been discussed in relation to the existing literature. Second, narrative texts have been examined as the text in this study is also a fictional narrative text. The reason why a narrative text was used in this study is that narrative texts are appropriate for foreign language learners as they evoke curiosity in them while reading and make them enthusiastic. Third, 'Rüşvet', a short story by Ömer Seyfettin, was introduced briefly and then the text was analyzed in terms of its lexical items and grammar before the modification. In this respect, lexical features including the number of vocabulary items, their word categories, the number of abstract and concrete items, and then the grammatical characteristics like the verb tenses, anaphoras and cataphoras were identified. Fourth, the text was modified at B1 level by taking all the aforementioned results of the text analysis into consideration. The modification was conducted by replacing the vocabulary items that have low frequency with higher ones and the words with figurative meanings with other vocabulary items carrying that figurative meaning in literal form, by reducing the adverbs or prepositions and by changing the dialects with the modern Turkish language. As to the modifications at sentence level, tense changes were made, anaphoras or cataphoras were made clearer, and the complex sentences were divided into a few parts. In conclusion, it is suggested that text modification should not solely be intuitional. If it is carried out by following the principles including both the selection of the text and the modification itself like the ones presented in this study, the modified text can save its authentic characteristics more. Thus, learners can still have access to the pragmatic structures and cultural aspects of the target language and the modification in this study can serve as an example to text modification in teaching Turkish as a foreign language. 


\section{Yabancı Dil Öğretiminde Metin}

Metin kavramı, en yalın ifadeyle Saussure'ün dil ve söz karşıtlı̆̆ından yola çıkılarak söze dökülen dilin yazıyla kalıcı hâle gelmesi olarak tanımlanabilir. Söylemler yazıya döküldüklerinde dahi söylem özelliklerini koruyarak sözcelem durumuna bağımlıyken metin sözcelem durumundan bağımsızdır (Korkut 2015: 176). Korkut'un (2015: 176) ifade ettiği gibi "her ikisi de birbirine eklemlenerek anlam yaratan ve belli uzunlukta bir bütün oluştursa da, metin tümcelerden oluşur, söylem ise sözcelerden". Dilidüzgün (2008: 23) ise alanyazında metin kavramının tanımı üzerine bir uzlaşı olmadığını fakat "tümcenin üstünde bir birim" ya da "tümceler dizisi” gibi tanımların eksik olacağını ifade etmektedir.

İletişimin temel birimi olan metinler, yabancı dil öğretiminde de önemli bir yere sahiptir ve iletişimsel yaklaşımın etkisiyle yaygınlaşan özgün malzeme kullanımı metin kullanımında da ön plana çıkmaktadır. Harmer (1991: 97), özgün malzemeleri dil öğrenicileri için değil, anadili konuşurlar için tasarlanmış gerçek dili içeren malzemeler olarak tanımlamıştır. Bu bağlamda, gazete, dergi, broşür, roman, hikâye gibi metin türleri özgün metinlere örnek olarak gösterilebilir. İkinci bir dil öğrenirken/edinirken öğreniciler hedef dilin konuşulduğu toplumun sosyal olarak aktif bir üyesi olabilmek için hedef dilin kültürünü ve kültüre ait işlevsel yapılarını da öğrenmektedirler (Ros i Solé 2007: 206). Öğreniciler özgün metin sayesinde hedef dilin kültürünü ve dilsel yapılarının bağlamda nasıl anlam kazandığını daha yakından ve gerçekçi bir biçimde gözlemleme olanağı bulabilmektedirler (Al Azri ve Al-Rashdi 2014: 251). Çünkü hedef dilin kültürüyle anlam kazanan deyimler, atasözleri ve metaforlar gibi dilsel ögeler özgün malzemelerde pedagojik amaçla hazırlanan malzemelere kıyasla daha fazla bulunmaktadır. Böylelikle öğreniciler, özgün metinler aracıllğıyla bu tür kültürel ögeleri hedef dilin sosyal ve kültürel bağlamlarında nasıl anlam kazandığını görebilirler.

Öte yandan, özgün metinler hedef dilin anadil kullanıcılarına yönelik hazırlandığı için ikinci/yabancı dil öğrenicileri özgün metinleri anlamak için yeterli dilbilgisi ve kelime bilgisine sahip olmayabilirler ve bunun sonucu olarak özgün 
malzemeyi kavramakta zorlanabilirler (Al Azri ve Al-Rashdi 2014: 252, Aziz vd. 2010: 216). Bu noktada, metni anlaşılır kılma işlemi değiştirimle gerçekleştirilmektedir. Durmuş (2013a: 392), değiştirim işleminin "hedef metin, kaynak metne bazı sözcüksel ve/veya sözdizimsel eklemeler yapılarak, kaynak metinden belirtilen düzeylerde bazı dilsel yapılar çıkarılarak veya kaynak metindeki yapılar hedef metin okuyucusunun nitelik ve beklentilerine uygun olan eş veya yakın değerli dilsel yapılarla değiştirilerek” gerçekleşebileceğini belirtmektedir. Metin değiştirimine yönelik geleneksel okunabilirlik formülleri ve sezgisel yaklaşımlar bulunmaktadır. Geleneksel okunabilirlik formülleri cümle ve kelime uzunluğuna dayanarak bir metnin zorluğunu ölçen Flesch-Kincaid indeksi gibi formüllerdir (Crossley, Allen ve McNamara 2011: 84). Ateşman da (1997) mevcut formüllerden uyarlayarak Türkçe için bir okunabilirlik formülü geliştirmiştir (aktaran Ülper, 2010: 105). Ancak yapılan çalışmalar bu tür okunabilirlik formüllerinin metindeki tutarl11ık, bağlaşıklık, metnin retorik yapısı gibi ögeleri inceleyemediğini ve bu nedenle özellikle yabancı dil öğrenenler için metin değiştirimini ölçmede uygun olmadığını göstermektedir (Crossley vd. 2011: 87, Durmuş 2013b: 140). Sezgisel yaklaşımda ise "ikinci/yabancı dil öğretim elemanlarının sadeleştirme yapmak durumunda kaldıklarında sadeleştirmenin niceliğini ve niteliğini belirlemek için genellikle kendi muhakeme yeteneklerine ve birikimlerine güvenmektedirler" (Durmuş 2013a: s.138). Yapılan çalışmalar metin değiştiriminin çoğunlukla sezgisel olarak yapıldığını göstermektedir (Crossley vd. 2011: 86, Durmuş 2013b: 145). Alanyazındaki çalışmaların birçoğu değiştirilmiş metinlerin özellikle düşük yeterlilik düzeyindeki ögrenicilerde daha iyi kavrama sağladığını ortaya koymuştur (Crossley 2018: 5, Oh 2001: 72, Safari ve Montazeri 2017: 74, Yano vd. 1994: 214). Bu doğrultuda, yabancı dil öğretiminde özgün metinleri dil öğretim sürecinden tamamen çıkarmak yerine metnin, değiştirim işlemleriyle öğrenci düzeyine uygun hâle getirilebileceği ve böylelikle özgün metnin özelliklerin belli ölçüde korunabileceği ileri sürülebilir.

\section{Anlatı metinleri}

Anlatının pek çok tanımı olmakla birlikte, en çok kabul edilenlerden biri Labov'a (1972) ait olan tanımdır. Labov (1972: 359-360) sözlü anlatıyı "yalnızca geçmiş deneyimlerin değiş̧tirilmeksizin söze dökülerek aktarımı" olarak tanımla- 
mıştır. Bu sebeple anlatılarda amaç bilgi vermek değil olayları anlatmaktır. Anlatı çözümlemesindeki ilk model Propp (1928) tarafından masalları çözümlemesiyle ortaya çıkmıştır (Aktaran Yazıcı 2013: 89). Daha sonraları, Labov (1972) sözlü anlatılardan yola çıkarak anlatının özelliklerini incelemiş ve bu özelliklerin evrensel olduğunu ve yazılı anlatılarda da bulunduğunu ortaya koymuştur (Aktaran Yazıcı 2013: 90). Labov (1972: 363) bir anlatının özet, tanıtım, karmaşık olaylar dizisi, değerlendirme, çözüm ve sonuç olmak üzere altı bölümden oluşan bir retorik şemaya sahip olduğunu ileri sürmüştür.

Anlatı metinleri hikâye düzlemi ve söylem/anlatım düzlemi olmak üzere iki düzlemden oluşmaktadır. Hikâye düzlemi "olayların zamansal sıraya göre dizildiği ve göndergesel bilginin aktarıldığı düzey” iken söylem/anlatım düzlemi "bu dizilerden oluşan bölümlerin bir tema çerçevesinde hiyerarşik bir yapıya göre düzenlendiği ve öykünün anlatıldığı, bakış açısının aktarıldığı düzey"dir (Koç 1993'ten aktaran Yazıcı 2017: 122). Anlatıcının söylem/anlatım düzleminde olayların kronolojik sıralamasını farklı bir şekilde aktarması mümkündür. Anlatı metinlerinin belirgin özelliklerinden biri de kullanılan zamandır. Labov (1972: 360-361), anlatı metinlerinde çoğunlukla geçmiş zamanın kullanıldı̆̆ını öne sürmektedir. Benzer şekilde, Dilidüzgün (2008: 123) anlatı metinlerinde geçmiş zamanın olayı bir bütünlük içinde sunduğunu ve en sık kullanılan bir diğer zaman çekimi olan şimdiki zamanın hikâyesinin de betimlemeler gibi ikincil durumları aktardığını ifade etmektedir.

Bir dilin büyük $\mathrm{K}$ kültürünün de parçası olan yazınsal metinlerden (Kramsch 2013: 58) edebî anlatı metinlerine gelince bu metin türünde "bir olay, bir olgu ya da bir öykü olayın kahramanlarının, birbirleriyle ilintili olayların belli bir zaman ve uzam içerisine oturtulmasıyla belirlenmiş bir anlatma düzeni izlenerek anlatılır" (Dilidüzgün, 2008, s.121). Edebi anlatı metinlerinin en belirgin özelliği ise içinde kurmaca bulundurmasıdır (Yazıcı 2013: 93). Roman, hikâye, masal gibi metinler kurmaca anlatı metinlerine örnek olarak gösterilebilir. Bu tür anlatı metinlerinde anlam, bilgilendirme amacı güdülmediği için örtük bir şekilde verilebilir. Bu durumda, "örtükleme bir strateji olarak anlatı metinlerinin sezdirimlerle (implication) ve bu sezdirimlerin sonucundaki çıkarımlarla (inference) metnin anlamlandırılmasını ve iletiye ulaşılmasını sağlar” (Yazıcı 2013: 93). 


\section{Değiştirim için metin seçim ölçütleri}

Yabancı dil öğretiminde özgün metin kullanımının/değiştiriminin yaygınlaşması, metin seçiminde göz önünde bulundurulması gereken ölçütlerin oluşturulmasını gerektirmektedir. Bu ölçütler dilbilgisel özellikler, içeriksel özellikler ve metnin derste işlenebilirliği olarak üç sınıfta incelenebilir.

Bir metnin öncelikle öğrenicilerin dil düzeyine uygun olması gerekmektedir. Yeniden yapılandırma aşamasında özgün metnin yapısını makul ölçüde değiştirebilmek için öğrencinin mevcut dil düzeyinin çok üstünde olmayan metinler seçilmelidir. Böylelikle Krashen'ın (1982) dilsel girdi varsayımı da göz önünde bulundurularak yeni dilsel yapılar öğrencilerin dil düzeylerine uygun derecede zor olur ve metnin anlaşı1ırlığı korunabilir. Dilsel yapıların yanı sıra, metnin söz varlığının da öğrencilere uygunluk açısından incelenmesi gerekmektedir. Sadeleştirmeyi asgari düzeyde tutabilmek için kullanım sıklığı yüksek kelimeler ve öğrencilerin bildiği varsayılan kelimeleri içeren metinlerin tercih edilmesine dikkat edilmelidir. Ayrıca Bakan'ın da (2012: 53) ifade ettiği gibi "ağır sanat11 söyleyişlerin, biçemsel özelliklerin bulunmadığ 1 , daha sade görüntüye sahip eserler" tercih edilmelidir. Çünkü deyimler ve metaforlar gibi değişmeceli anlam içeren kullanımlar örtük anlam içermektedir. Bu tür kullanımlardaki örtük iletinin kavranması kültürel artalan bilgisi de gerektirebileceği için öğrencilerin düzeyinin üstünde ise metaforik dil kullanımının olduğu metinler tercih edilmemelidir.

Bunların dışında, çok uzun, eksiltili ve devrik yapılı cümlelerin bulunduğu metinler de her düzeye uygun olmayabileceği için bu yapıların metindeki dağılımı ve metnin tutarlılığı metin seçiminde dikkate alınmalıdır. Ülper (2010: 105) bununla ilgili olarak okunabilirlik başlığ 1 altında uzun kelime ve cümlelerin kısa olanlara göre daha zor okunduğunu ve dolayısıyla anlamlandırmasının da zor olabileceğini öne sürmektedir. Ayrıca Diller İçin Avrupa Ortak Öneriler Çerçevesi'nde de (2013: 162) "birçok yan cümleden oluşan uzun tümcelerin" ve "kopuk öğelerin" anlaşılırlığı düşüreceği belirtilmektedir. Çok fazla edat ve bağlaçların bulunduğu cümlelerin anlaşılırlığı da öğrenciler için zorlayıcı olabilecektir. Metnin ağız ve şive özellikleri içermemesi de seçim sürecinde dikkat edilmesi gereken bir başka husustur (Bakan 2012: 51). Son olarak, anlatı metinlerinde zamansal sıçramalar oldukça yaygındır. Fakat bu zamansal sıçramalar kro- 
nolojik olarak verilmediği takdirde düşük yeterlilik düzeyindeki öğrenciler metni anlamakta zorluk yaşayabilir. Bu nedenle olayların kronolojik olarak sunulduğu söylem yapılarını içeren metinlerin tercih edilmesi öğrenciler için daha uygun olabilecektir.

Metnin içeriksel özelliklerine gelince öğrenicinin konuyu anlaması için hedef dile dair yoğun kültürel artalan bilgisi gerektirmeyen evrensel temalara dayanan ve ilgilerini çekecek bir konu içeren metinler tercih edilmelidir. Durmuş’a göre (2019: 56) kültürel tarafsızlığın bulunduğu doğa olayları, yaşam, arkadaşlık gibi evrensel temalar öğrenciler arasında çatışma çıkma olasıllığını düşürecek ve öğrenci katılımını arttıracaktır. Bunlara ek olarak, Ülper (2010: 102) öğrencilerin artalan ve dünya bilgilerinin üzerinde konu içeren bir metnin okunabilirliğinin düşük olacağını iddia etmektedir. Çünkü öğrenci okuduğu metindeki kavramları daha önce gördüyse bu kavramları anlamlandırması daha kolay olacaktır. Bu durumda öğrenci artalan bilgisinin yetersiz kaldığı bir konuyu içeren bir metin okuduğunda kelimeleri anlamakta zorluk yaşayabilir. Metin seçerken dikkat edilmesi gereken bir başka nokta da metnin uzunluğudur. Ders süresi dikkate alınarak sınıf bağlamında işlenebilecek uzunlukta metinlerin yapılandırma için tercih edilmesi önemlidir.

\section{"Rüşvet” Adlı Hikâyenin Seçilme Nedenleri}

Bu çalışmada kullanılacak metni seçerken yukarıda değinilen ölçütler de göz önünde bulundurularak bir kurmaca anlatı türü olan ve Ömer Seyfettin tarafından yazılan "Rüşvet" adlı kısa olay hikâyesi seçilmiştir (Ek 1'e bakınız). Hikâye, bir kurmaca anlatı metni olduğu için öğrencilerin birinci dillerinde kodlanmış anlatı retorik şeması aracılığıyla metnin yapısını kolaylıkla anlayabilecekleri düşünülmüş̧ür. Metnin dilbilgisel özelliklerine gelince anlatıda çok fazla uzun cümle bulunmaması, İstanbul ağzıyla yazılarak ağız ve şive özelliklerinin kullanılmaması, deyimler gibi yoğun artalan bilgisi gerektiren kelime gruplarının olmaması, kullanım sıklığı düşük kelime sayısının az olması, çok yoğun sanatlı söyleyişler olmaması, fakat günlük dil kullanımının olması bu metnin seçilmesinde etkili olmuştur. Bunlara ek olarak metinde olaylar anlatının retorik şemasına uygun bir biçimde ve kronolojik sırada verilmiştir. Zamansal atlamanın açıkça be- 
lirtilmesinin de öğrencilerin kavramasını kolaylaştıracağı yönünde yorumlanmıştır. Hikâyede, hikâyeleme ve anlatı zamanlarının dilbilgisel işaretlerle sezdirildiği görülmüş̧ür. Bu durumun, metnin retorik yapısının ve bu iki zaman farkının anlaş1masına yardımcı olacağı düşünülmüştür.

Metnin her kültürde karşılaşabilecek evrensel bir değer olan dürüstlükhilekârlık teması çerçevesinde şekillenmesi ve yoğun kültürel artalan bilgisi gerektirmeyen bir konuya sahip olması seçim sürecinde etkili olmuştur. Ayrıca selamlaşma edimleri, dolaylı ricada bulunma, kabul etme gibi Türkçenin söylemsel özelliklerini yansıtan söz edimlerinin kullanılmasının, kültüre özgü dil ögelerinin öğretilmesi bakımından önemli olduğu düşünülmüştür. Metin, bir olay hikâyesi olduğu için öğrencilerin ilgisini çekeceği ve merak duygularını yüksek düzeyde tutacă̆ 1 ön görülmüştür. Son olarak, metnin uzunluğunun sınıf içinde kullanıma ve yeniden yapılandırmaya uygun olduğuna karar verilmiştir.

\section{Yeniden Yapılandırılacak Anlatı Metninin Türü, Konusu ve}

\section{Retorik Yapısı}

Bu çalışmada, Maupassant tarzı hikâye olarak da bilinen olay hikâyeciliğinin en önemli ismi olarak kabul edilen Ömer Seyfettin tarafindan yazılan bir hikâye olan "Rüşvet” B1 düzeyine göre yeniden yapılandırılacaktır. Metin, Avukat Hacı Namık Efendi ve Ali Hoca olmak üzere iki ana karakter ve Ali Hoca'nın hasmı olan muhtar Huysuzoğlu ile üç kişiden oluşmaktadır. Ömer Seyfettin hikâyede haksız olan Ali Hoca'nın haksız olduğunu bilerek söz konusu konu ile ilgili hasmına dava açması ve bir hile ile davayı kazanmasını ele almaktadır. Olay, çoğunlukla avukatın "dükkân”1 olarak işaret edilen yerde geçmektedir. Ancak zamanla ilgili bir bilgi yoktur.

Metnin retorik yapısına bakıldığında Labov'un (1972) anlatı retorik şemasının bölümlerini görmek mümkündür. Söz konusu anlatı metni özetsiz, olayın geçtiği yeri tasvir eden tanıtım bölümüyle başlamaktadır.

“(1) Çarşı meydanının büyük çınar ağaçları, yere düşen gölgelerini alacalandirarak, fisıldiyorlardl. (2) Kuvvetli bir rüzgâr esiyordu."

Bunu takiben görülen geçmiş zaman ekinin kullanımıyla da sezdirilerek karmaşık olaylar dizisinin geldiği ve Labov'un da (1972: 360) ifade ettiği gibi olayların bir akış içinde anlatıldığı görülmektedir. 
“(3) Avukat Hacı Namık Efendi, kâğıtlarım uçmasın diye, zümrüt bir kameriyeye benzeyen küçük dükkânının camlarını indirdi.

(4) Sonra gitti, açık kapıyı iterken heybesi omuzunda, semerli atının yuları elinde, sarıkl, kısa boylu yuvarlak bir köylünün yaklaştı̆̆ını gördü”

Hikâyede olaylar kronolojik olarak oluş sırasına göre verilmiştir. Daha önce de ifade edildiği gibi anlatı metinlerinde en çok kullanılan zamanlar geçmiş zaman ve şimdiki zamanın hikâyesidir. Bu metinde de en çok görülen geçmiş zamanın kullanıldığ1 görülmektedir. Metnin ilerleyen bölümünde ise zaman zaman anlatıcının olaylar dizisini aktarmayı bırakıp değerlendirme yaparak olayın avukat için olan önemini okuyucuya gösterdiği ve olayın çözümünü geciktirdiği görülmektedir.

“(38) Namık Efendi haksız davaları alamazdı. (39) Ali Hoca'nın vekâlet teklifini reddetmek istiyordu. (40) Fakat, "Bozoyük” köyünün halkı otuz senelik müşterileriydi. (41) Eşek, ahırını beller gibi onun dükkânını bellemişler, hükümetteki her işleri için ona müracaatı âdet edinmişlerdi. (42) Kışlık zahîresi de hemen hemen tamamiyla oradan gelirdi."

Böylelikle anlatıcı aynı zamanda hikâye düzleminden çıkarak söylem/anlatım düzlemine geçmektedir. Ayrıca bu değişiklik görülen geçmiş zaman ekinin kullanımından geniş zamanın hikâyesine olan geçiş aracılığıyla dilbilgisel işaretlere de yansımaktadır. Dilbilgisel işaretlerdeki değişimi metindeki diğer değerlendirmelerde de görmek mümkündür.

"(53) Ali Hoca avukatının heyecanını anlayamıyordu. (54) Ondan yeni hâkimin medhini uzun uzadlya dinledi. (55) Bu zat rüşvetin, hediyenin korkunç bir düşmanıymış! (56) En hakl bir davacı kendisine rüssvet vermeye teşebbüs etse, o saatte onu haksız çıkarırmış!"

“(61) Avukat ümitsizdi. (62) Bu işi hatır için alıyordu. (63) Haksızlık o kadar meydanda idi ki..."

"(68) Bu kadar haksız bir hükmü hâkimin nasll verdiğine bir haftadır şaşlyordu."

İncelenen kurmaca anlatı metninde, anlatıcı üçüncü şahıs olarak yer almaktadır ve olayları müşahit bakış açısıyla aktarmaktadır. Bu tür anlatıcı, olayların 
dışında kaldığ 1 için "dış" odakla gördüklerini bir kameraman tarafsızlığıyla okurlara aktarır (Bakır 2015: 36). Bu nedenle okur metindeki kahramanların iç dünyasıyla ilgili sınırlı bilgiye sahip olur ve daha çok çıkarımlarda bulunur. Üçüncü şahısla çekimlenmiş eylemlerle anlatıcının izlerini hikâyede görmek mümkündür. Diğer taraftan, zaman zaman anlatıcı bakış açısı hikâyeden silinmiş ve anlatıcı, hikâye ve okurun arasından çekilmiştir. Aşağıdaki cümleler buna örnek olarak gösterilebilir.

“-(8) Aleyküm selam, Namık Efendi! (9) Belaya düşüm. (10) Bir dava için geliyorum...(11) diye başını salladı.

- (12) Ey, gel, biraz konuşalım bakalım.

-(13) Konuşalım.

-(14) Derdini anlat bana bakayım.

-(15) Senden başka zaten kime anlatacağım?"

\section{Metnin Çözümlemesi}

Metni yeniden yapılandırmadan önce hikâye, kelime ve dilbilgisi düzeylerinde bağlaşıklık çerçevesinde çözümlenmiştir. Bir metinde bağdaşıklık "birden çok tümce ya da tümceciğin uygun 'bağlantı öğeleri' ile birbirine eklenmesi ve anlamsal olarak birbiriyle çelişmemesi” (Korkut 2015: 178); bağlaşıklık (anlamsal tutarlılık) ise Onursal'ın (2003: 29) belirttiği gibi "derin yapıda oluşan anlamlar arasındaki mantıksal bağlantıdır”. Başka bir anlatım ile metindeki iletilerin dil içi ve dil dışı dünya ile uyumlu olmasıdır.

\section{Kelime düzeyinde çözümleme}

Hikâyedeki kelimeler arasındaki ilişki incelendiğinde şu görünümler elde edilmiştir. Öncelikle hikâye 484 kelimeden oluşmaktadır. Bu kelimelerden isim soylu olanların fiil soylulardan daha fazla kullanıldığı görülmüştür. Fiil soylu kelimeler fiiller dışında ad-eylem, ortaç ve ulaçlardan da oluşmaktadır. Ayrıca hikâyede somut adların soyut adlara kıyasla sayıca daha fazla kullanıldığı görülmektedir.

Hikâyede çok sayıda kelimenin temel anlamı dışında yan anlamda kullanıldığ1 görülmüştür. Düzanlam bir kelimenin anlamlaması, yani en değişmez 
anlamıken yananlam ilgili kelimenin anlambirimcik demetine yeni bir gücülbirim, başka bir ifadeyle yeni bir anlambiricimciğin eklenmesiyle oluşan anlamdır (Eziler Kıran 2015: 74). Bu kullanımların bir kısmı aşağıda gösterilmiştir.

Tablo 1. Temel Anlamı Dışında Kullanılan Kelimeler

(1) Çarşı meydanının büyük çınar ağaçları, yere düşen gölgelerini alacalandırarak, fisıldıyorlardı.

(2) Kuvvetli bir rüzgâr esiyordu.

(3) Avukat Hacı Namık Efendi, kâğıtlarım uçmasın diye, zümrüt bir kameriyeye benzeyen küçük dükkânının camlarını indirdi.

Metinde kelime düzeyinde bağlaşıklı̆̆ın gerçekleşmesini sağlayan ögelerden biri de yinelemelerdir. Yineleme, "bir sözcüğün anlamının metinde daha önce kullanılmış bir sözcüğün anlamını çeşitli biçimlerde anımsatmasını içerir" (Oktar 1997'den aktaran Taşıüzel 2004: 77). Metinde en çok yinelenen kelimelerden birinin "dedi” kelimesinin olması (altı kez) anlatı metninin özelliklerinden olan karşılıklı konuşmaları aktarma eylemlerinin kullanımını kanıtlar niteliktedir. En sık yinelenen kelimeler aşağıda gösterilmiştir.

1. dedi (5), dememiş miydin (1)

2. haksizsin (2), haksız (5), haklı (3), haksizlık (1)

3. dava (1), davasını (2), davadan (2), davaları (1), davay1 (2), davacı (1)

4. avukat (2), avukatın (1), avukatının (1)

Kelime düzeyinde bağlaşıklığ oluşturan bir diğer yineleme unsuru metinde aynı sözlüksel alana sahip kelimelerin kullanılmasıdır. Sözlüksel alan "en az bir anlambirimcikle birbirine bağlanan, en az bir anlambirimcikle farklılaşan sözcüklerin oluşturduğu alan” olarak tanımlanmaktadır (Eziler Kıran, 2015, s. 77). İncelenen hikâyede aynı sözlüksel alanda kullanılan kelimeler şu şekildedir:

1. dava, belaya düşmek, hasım, haksız, haklı, davadan vazgeçmek, davayı kaybetmek, davayı kazanmak, dava almak, vekalet, hakim, davacı, avukat, hüküm vermek, rüşvet, düşman.

2. dükkân, yazıhane, sedir, peyke

3. Köylü, sarıkl1, yular, at, heybe

4. Çınar ağaçları, ceviz, rüzgâr, esmek, uçmak, fisıldamak

4. Gölge, alacalandırmak, parlamak, 
Yukarıda belirtilen söz varlığı çözümleme bulguları sadeleştirme sürecinde anlam bütünlüğünü bozmamak için öğrenicilerin düzeyine göre korunacak ya da düzeylerine uygun şekilde değiştirilecektir.

\section{Dilbilgisi düzeyinde çözümleme}

Bir metinde anlamsal tutarlılık kelime düzeyine ek olarak dilbilgisel ögeler arasındaki ilişkiye de dayanmaktadır. İncelenen anlatı metninin dilbilgisel özellikleri ile ilgili genel görünüm şu şekildedir. Metindeki en uzun cümle 24 kelimeden oluşmaktadır. Uzun cümleler çoğunlukla virgül “," ile birbirinden ayrılmıştır. "dedi” kelimesinin kullanımıyla kahramanların konuşmaları doğrudan aktarılmıştır. Bu cümleler aşağıda gösterilmiştir.

(5) "Merhaba Ali Hoca, dedi, böyle vakitsiz ne arıorsun burada?"

(27) "Sen haksizsin Ali Hoca! dedi."

(44) "Kaybedince bana darlmayacaksin! dedi."

(58) "Namık Efendi: - Amin, amin! dedi."

(67) "Hoşgeldin be! Ne dersin, davay kazandı! dedi."

Metinde karşılıklı konuşmaların çoğunlukla soru cevap şeklinde geliştiği görülmektedir. Buna dayanarak metnin günlük konuşmadaki gibi gerçek iletişim durumlarını yansıttığı söylenebilir. Metindeki soru cümlelerinden bazıları aşağıda gösterilmiş̧ir.

(47) "-Hâkime güzel bir koç göndersem?.."

(48) "-Ne?.."

(49)" - O vakit davayı kazanamaz mıyım?"

(50) "—O vakit hiç şüphesiz kaybedersin işte!..”"

Anlatı metninde gerçek iletişim durumlarını yansıtan bir başka unsur söz edimleridir. Hymes (1972), iletişimsel yetiyi açıklarken söz edimleri üzerinde durmaktadır ve iletişimsel yetiyi dil kullanıcılarının söz edimlerini kullanabilmeyi başarabilme, bu edimlerle sözlü iletişime katılabilme ve diğerlerinin söz edimleri kullanımını değerlendirebilme becerisi olarak açıklamaktadır (Aktaran Wardhaugh ve Fuller 2015: 231). Söz edimleri, dile getirildiğinde soru sorma, emir verme, rica etme gibi eylemlerin gerçekleştirilmesini sağlayan işlevsel birimlerdir (Yule 1996: 47). İncelenen anlatı metninde selamlaşma, rica ve kabul söz edimle- 
rinin kullanıldığı görülmüştür. Rica ve kabul söz edimlerinin bulunduğu ifadeler aşağıda gösterilmiştir.

\section{Rica söz edimleri}

Kabul söz edimleri

(9) Belaya düştüm. (10) Bir dava için geliyo- — (12) Ey, gel, biraz konuşalım rum...(11) diye başını salladı. bakalım.

- (15) Senden başka zaten kime anlatacağım?

(43) Pekâlâ, senin bu işine bakayım.

Yukarıdaki rica söz edimleri incelendiğinde, bunların dolaylı söz edimleri olduğu görülmektedir. Dolaylı söz edimleri dilsel yapı ve işlev doğrudan ilişkili olmadığında gerçekleşmektedir (Searle 1979: 30). Yukarıdaki rica söz edimlerinin birincisinde hikâyenin kahramanlarından Ali Hoca avukatın yardımına olan ihtiyacını dile getirerek rica dolaylı bir şekilde gerçekleştirmiştir. İkinci rica edimine Brown ve Levinson'ın (1978) incelik kuramı çerçevesinde bakıldığında aynı kahramanın bu kez avukatın bu dava için ne kadar bilge ve önemli olduğunu sezdirerek avukatın "olumlu yüz"üne hitap ederek rica edimini oluşturduğu görülmektedir. Olumlu yüz, başkaları tarafından onaylanma isteğine işaret ederken olumsuz yüz, eylem özgürlüğüne sahip olma ya da bağımsız olma isteği ile ilgilidir (Brown \& Levinson, 1978: 70). Kabul söz edimlerine gelince (12) numaralı sözce incelendiğinde avukatın konuşmayı kabul etmesine rağmen rahatsız olduğu ve olumsuz yüzünün zarar gördüğü öne sürülebilir. Fakat avukat bunu doğrudan dile getirmemektedir. Söz edimlerindeki bu dolaylılığın sebebi bir kültürün kendine özgü toplumsal özellikleri ile açıklanabilir. Yemenici (1996: 38) Türk toplumunun iletişimde doğrudan ifadeler kullanmak yerine daha çok dolaylı ifadeler kullandığını, kişilerin iletiyi bağlamdan çıkarmalarının beklendiğini ifade etmektedir. Bu doğrultuda anlatı metnindeki söz edimlerinin Türk toplumundaki gerçek iletişim durumlarını yansıttığı öne sürülebilir.

Bunlara ek olarak, metinde eksiltili cümleler bulunmaktadır. Günlük konuşma dilinde eksiltili ifadelerin fazlaca kullanıldığı göz önüne alınırsa metnin bu eksiltilerle gerçek dilsel girdileri/konuşmaları yansıttığı düşünülebilir. Eksiltili cümlelerden örnekler aşağıda koyu harflerle gösterilmiştir. 
- (14) Derdini anlat bana bakayım.

- (15) Senden başka zaten kime anlatacağım? (derdimi)

- (28) Haksız myım?

- (29) Evet. (haksizsin)

— (74) Evet, ama sen bana "Rüşvet düşmanıdır (hâkim), kim hediye verirse (hâkime) haksız çıkar" dememiş miydin?

Artgönderim ve öngönderime gelince bir metinde bağlaşıklık izleksel devamlılı̆̆ sağlayan bazı öğelerin yinelenmesiyle de gerçekleşmektedir. Bu yinelemelerden birinci tür "daha önce ifade edilmiş olan bir izleğin ya da yeni bilginin daha sonra yinelenmesi" olarak açıklanan artgönderimdir (Korkut 2015: 187). İncelenen metinden bir aynı adla artgönderim örneği şöyledir;

“(1) Çarşı meydanının büyük çınar ağaçları, yere düşen gölgelerini alacalandırarak, fisıldıyorlard1. ... (82) Meydandaki büyük çınar ağaçlarının derin fislltıları, kapıda ayakta duran Ali Hoca'nın yanlarından, tepesinden, bacaklarının arasından giriyor, duvarlarına eski vilayet gazeteleri yapıştırılmış dükkâncı̆̆ın içini dolduruyordu..."

Öngönderim ise "daha sonra açıklanacak olan bir sözcük veya söz öbeğinin, söz dizimi içince daha önce yer almasıdır” (Korkut 2015: 188). Örneğin, incelenen hikâyedeki karakterlerden olan Ali Hoca okuyucunun karşısına önce "köylü" olarak çıkmaktadır.

“(4) Sonra gitti, açık kapıyı iterken heybesi omuzunda, semerli atının yuları elinde, sarlkll, klsa boylu yuvarlak bir köylünün yaklaştığını gördü:

“- (5) Merhaba Ali Hoca, dedi, böyle vakitsiz ne artyorsun burada?

Anlatı metinleri geçmiş deneyimler hakkında oldukları için bu tür metinlerdeki cümleler çoğunlukla geçmiş zaman eylemleri içermektedir. İncelenen anlatı metninde de buna benzer şekilde cümlelerde en sık (34 kez) görülen geçmiş zaman ekinin kullanıldığı görülmüştür. Anlatı metninde görülen geçmiş zaman eki kullanımının sayıca fazla olmasının yanı sıra farklı eylem zamanlarının kullanımıyla hikâye ve anlatı zamanları arasındaki fark da ortaya çıkmaktadır. Çünkü anlatı metinlerinde zaman zaman hikâye düzlemi dursa da anlatııı başka bir bilgi verirken söylem/anlatım düzlemine geçmektedir ve bu sırada dilbilgisel 
işaretleme de değişmektedir. Dilbilgisel işaretlemelerdeki değişimler sayesinde öğrencilerin hikâye ve söylem/anlatım düzlemleri arasındaki geçişleri daha kolay anlayabileceği öne sürülebilir.

Yazıcı (2013: 93), kurmaca anlatı metinlerinde bilgilendirici metinlerin aksine iletinin örtük bir şekilde verildiğini ve bunun sezdirim ve sezdirime dayanan çıkarımlarla gerçekleştiğini ifade etmektedir. Örneğin, hikâyedeki avukata ait "Merhaba Ali Hoca, dedi, böyle vakitsiz ne arıorsun burada? Daha pazara iki gün var..." cümlesinden avukatın Ali Hoca'nın gelişinden rahatsızlık duyduğu sezilmektedir. Bu durum, Yemenici'nin (1996: 38) Türk toplumu gibi bağlama çok duyarlı olan ve dolaylı anlatımın yaygın olduğu toplumlarla ilgili yargısı ile de örtüşmektedir. Yemenici (1996: 38), bu tür toplumlarda duyguların ayıplanma korkusuyla açıkça dile getirilmediğini, sezdirimlerle anlaşılmasının beklendiğini ifade etmektedir. Şu cümleler çıkarıma örnek olarak gösterilebilir. "Namık Efendi haksız davaları alamazdı. Ali Hoca'nın vekâlet teklifini reddetmek istiyordu. Fakat 'Bozoyük' köyünün halkı otuz senelik müşterileriydi. Eşek, ahırını beller gibi onun dükkânını bellemişler, hükümetteki her işleri için ona müracaatı âdet edinmişlerdi. Kışlık zahîresi de hemen hemen tamamıyla oradan gelirdi.” Bu cümlelerden avukatın davayı kişisel çıkarları için alacağı çıkarımı yapılabilmektedir.

\section{"Rüşvet" Adlı Hikâyenin B1 Düzeyine Uyarlanması}

Bu çalışmada, "Rüşvet" adlı hikâye Diller İçin Avrupa Ortak Öneriler Çerçevesi’ne göre öğrenicilerin B1 düzeyinde bilmeleri gerektiği varsayılan yeterliliklere ve B1 düzeyinde işlenen dilbilgisi konularına göre yeniden yap1landırılacaktır. Özgün metinde nedenleştirme amacıyla "diye” kullanıldığı görülmüştür. Ankara Üniversitesi TÖMER'de bu yap1 B1 düzeyin son evrelerine doğru öğretildiği için B1 düzeyine göre bir adım zor olarak (i+1) kabul edilmiş, öğretilmesi hedeflenerek değiştirilen metinde korunmuş ve metne uygun başka yerlerde de eklenmiştir.

\section{Söz varlığı düzeyinde değiştirim}

Durmuş'a göre (2013a: 401) hedef öğrenci grubunun bilmediği düşünülen düşük kullanım sıklı̆ğ olan kelimeler, bir uzmanlık ile ilgili kelimeler, değişmeceli anlamda kullanılan deyimler veya metaforlar metinden çıkarılabilir. Bunların 
yerine kullanım sıklığı daha yüksek kelimeler, eş ve yakın anlamlı kelimeler kullanılabilir. Bunun dışında zaman zaman açımlama ile de sadeleştirme yapılabilir. "Açımlama, hedef kitlenin anlamasının önünde engel olarak görülen sözcüksel yapıların yerine onların eş anlamlısı olan veya bir ifade şeklinde bu sözcükleri açıklayan sözcük veya sözcük gruplarının kullanımı ile ortaya çıkmaktadır" (Durmuş 2013a: 399). Bu doğrultuda yapılan değişimler Tablo 2'de gösterilmiştir.

Tablo 2. Kullanım Siklığı Düşük Kelimelerin Değiştirimi

\section{Özgün Metin}

\section{Değiştirilmiş Metin}

(1) Çarşı meydanının büyük çınar ağaçları, (1) Çarşı meydanındaki büyere düşen gölgelerini alacalandırarak, fısıl- yük çınar ağaçlarının gölgeleri dıyorlardı. rüzgârla hareket ediyordu.

(3) Avukat Hacı Namık Efendi, kâğıtlarım uçmasın diye zümrüt bir kameriyeye benzeyen küçük dükkânının camlarını indirdi.

(3) Avukat Hacı Namık Efendi, kâğıtlarım uçmasın diye yeşil bir çardağa benzeyen küçük dükkânının camlarını indirdi.

(4) Sonra gitti, açık kapıyı iterken heybesi (4) Sonra gitti, açık kapıyı iteromuzunda, ... ken çantası omuzunda, ...

(19) Heybesini yanına koydu (19) Çantasını yanına koydu (16) Atının yularını peykenin destek direğine bağladı. (16) Atının yularını tahta sedirin destek direğine bağladı.

(20) Namık Efendi'nin uzattığı tabakadan sigara sararken davasını anlattı. (20) Namık Efendi'nin uzattığ sigara kutusundan sigara sararken davasinı anlattı.

(21) Hasmı, köyün muhtarı Huysuzoğlu>ydu.

(78) Hasmım, muhtar Huysuzoğlu'nun ismini verdim.

(21) Düşmanı, köyün muhtarı

Huysuzoğlu>ydu.

(78) Düşmanım, muhtar

Huysuzoğlu'nun ismini verdim. 
(41) Eşek, ahırını öğrendiği

(41) Eşek, ahırını beller gibi onun dükkânını gibi onun dükkânını öğrenbellemişler, hükümetteki her işleri için ona mişler, hükümetteki her işleri müracaatı âdet edinmişlerdi için ona müracaatı alışkanlık hâline getirmişlerdi.

(42) Kışlık tahılı da hemen

(42) Kışlık zahîresi de hemen hemen tamamiyla oradan gelird hemen tamamiyla oradan gelirdi.

(54) Ondan yeni hâkimin

(54) Ondan yeni hâkimin medhini uzun uzadiya dinledi. övülmesini uzun uzadıya dinledi.

(55) Bu kişi rüşvetin,

(55) Bu zat rüşvetin, hediyenin korkunç bir düşmanıymış!

hediyenin korkunç bir düşmanımmış!

(56) En haklı bir davacı kendisine rüşvet vermeye teşebbüs etse o saatte onu haksız çıkarırmış (56) En haklı bir davacı kendi(65) Namık Efendi bir arzuhâl yazıyordu. (67) Hoşgeldin be! Ne dersin, davayı kazandik!

(82) (... ) duvarlarına eski vilayet gazeteleri yapıştırılmış dükkâncığın içini dolduruyordu... sine rüşvet vermeyi denese $o$ saatte onu haksız çıkarırmış (65) Namık Efendi bir dilekçe yazıyordu.

(67) Hoş geldin be! Davayı kazandik!

(82) (...)duvarlarına eski şehir gazeteleri yapıştırılmış dükkâncığın içini dolduruyordu...

(68) Bu kadar haksız bir hükmü hâkimin nasıl verdiğine bir haftadır şaşıyordu. (68) Bu kadar haksız bir kararı hâkimin nasıl verdiğine bir haftadır şaşıyordu.

Ayrıca yananlamılla kullanılan kelimeler aynı anlamı temel anlamıyla verecek kelimelerle değiştirilebileceği (Durmuş 2013a: 402) önerisine dayanarak metindeki yananlamlı kelimelerin bazıları değiştirilmiştir. Bu değişimler Tablo 3'te gösterilmiştir. 
Tablo 3. Yan Anlamlı Kelimelerin Değiștirimi

\section{Özgün Metin}

Değiştirilmiş Metin
Yapılan Değiştirim İşlemi

(4) Sonra gitti, açık kapıyı iterken heybesi omuzunda, semerli atının yuları elinde, sarıklı, kısa boylu yuvarlak bir köylünün yaklaştığını gördü:

(4) Sonra gitti, açık kapıyı "yuvarlak" kelimesi iterken heybesi omuzunda, yerine aynı anlamı semerli atının yuları elinde, temel anlamıyla karsarıklı, kısa boylu kilolu bir ş1layacak "kilolu" keköylünün yaklaştığını gördü: limesi kullanılmıştır.

(5) Merhaba Ali Hoca, dedi, böyle vakitsiz ne arıyorsun burada?

(5) Merhaba Ali Hoca, dedi, böyle uygun olmayan bir zamanda ne ariyorsun burada?

"vakitsiz" kelimesi

metinden çıkartılmış, açımlama ile aynı anlamı veren "uygun olmayan bir zamanda" söz grubu ile değiştirilmiştir.

"belaya düşmek" ye-

(9) Belaya düştüm.

(9) Bir bela var. rine aynı anlamı veren "bir bela var" söz grubu kullanılmıştır.

"kabullenmeye kalkıyordu" söz grubu (23) Şimdi o, neden sonra bu (23) Şimdi o, neden sonra bu daha temel anlamlı binayı kabullenmeye kalkı- binayı sahiplenmek istiyoryordu.

du. olduğu düşünülerek "sahiplenmek istiyordu" söz grubuyla değiştirilmiştir.

"ses çıkarmamak"

(31) Neye binayı yaparken sesini çıkarmamış?

(32) Çıkarmasın.
(31) Niye binayı yaparken itiraz etmemiş?

(32) İtiraz etmesin. söz grubu temel anlamıyla aynı anlamı veren" itiraz etmek söz grubu ile değiştirilmiştir. 
"böyle doğrular" değiştirim cümlesindeki "doğrular" keli-

(57) Ali Hoca: - Allah böy- (57) Ali Hoca: - Allah böyle doğruları dünya yüzün- le dürüst insanları dünyaden eksik etmesin! dan eksik etmesin!

mesi yerine "dürüst" kelimesi kullanarak değiştirim cümlesi tamamlanmış ve “yüzünden" kelimesi kaldırılmıştır.

Temel anlamı dışın-

(82) Meydandaki büyük ç1-

(82) Meydandaki büyük ç1nar ağaçlarının derin fisıltıları, ... nar ağaçlarının rüzgârda
çıkardığı sesler, ... da kullanılan "fisıltı" yerine "rüzgârda çıkardığı sesler" kelimesi kullanılmıştır.

Durmuş (2013a: 402), zarfların, edatların, ulaçları ve ortaçların öğrenicinin düzeyine uygun olmadığı takdirde "bağımsız tümce veya bağlaçla birbirine bağlanmış iki bağımlı tümceye ya da tek kelime veya ikileme biçimindeki kelimelerden oluşan zarflara" dönüştürülebileceğini önermektedir. Bu bağlamda, çözümleme sonucunda anlatımı sadeleştirmek için "Rüşvet” adlı hikâyedeki zarflar, ulaçlar ve ortaçlar incelenerek daha az miktarda kullanmaya çalışılmıştır. Bu çerçevede yapılan değiştirimler aşağıdaki tabloda sunulmuştur (Tablo 4'e bakınız).

Tablo 4. Kelime Düzeyinde Zarf, Edat, Ulaç Ve Ortaç Değiştirimi

\section{Özgün Metin \\ Değiştirilmiş Metin \\ Yapılan Değiştirim İşlemi}

(22) Ona ait bir arsanın üzerine Ali Hoca vaktiyle bir bina yaptırmıştı.
(22) Ona ait bir arsanın üzerine Ali Hoca bir bina yaptırmıştı
Eylemdeki görülen geçmiş zamanın hikâyesi kullanımı yapılan eylemin uzak geçmişte olduğu anlamını verdiği için "vaktiyle" zarfı çıkarılmıştır. 
(23) Şimdi o, neden sonra bu binayı kabullenmeye kalkıyordu.
(23) Şimdi Huysuzoğlu, arsa kendisinin diye bu binayı sahiplenmek istiyordu. "neden sonra" zarfı bağ-

laşıklığı etkilemediği için çıkarılmıştır. Ayrıca öğretilmesi hedeflenen "diye" nedenleştirme edatı eklenerek cümle yeniden oluşturulmuştur.

"uzun uzadıya" zarfi "uzadıya" kelimesinin anlaşılması zor olabileceğinden "uzun uzun" olarak değiş̧tirildi.

(56) En haklı bir davacı kendisine rüşvet vermeye teşebbüs etse, $\mathbf{o}$ saatte onu haksız çıkarırmış

(54) Ondan yeni hâkimin övülmesini uzun uzun dinledi.
(56) En haklı bir davacı

kendisine rüşvet vermeyi "o saatte" zarfi cümleden denese, onu haksız çıka- ç̧karılmışır.

rırmış
(42) Kışlık zahîresi de hemen hemen tamamıyla oradan gelirdi.
(42) Kışlık tahılı da çoğunlukla oradan gelirdi. "hemen hemen" ve "tamamıla" çıkartılarak aynı anlamda olan "çoğunlukla" eklenmiştir.

Bunların yanı sıra metinde çok az olan halk ağzı kullanımları da değiştirilerek İstanbul ağzıyla yeniden yazılmıştır. Bu değiştirimler şöyledir:

Tablo 5. Halk Ă̆zı Kullanımlarını Değiştirme

\begin{tabular}{ll}
\hline \multicolumn{1}{c}{ Özgün Metin } & \multicolumn{1}{c}{ Değiştirilmiş Metin } \\
\hline (12) Ey, gel, biraz konuşalım bakalım & $\begin{array}{l}\text { (12) Tamam, gel, biraz konuşalım } \\
\text { bakalım }\end{array}$ \\
\hline $\begin{array}{l}\text { (31) Neye binayı yaparken sesini çıkarma- } \\
\text { mış? }\end{array}$ & $\begin{array}{l}\text { (31) Niye binayı yaparken sesini } \\
\text { çıarmamış? }\end{array}$ \\
Darılmam ama neye kaybedeceksin? & Darılmam ama niye kaybedeceksin? \\
\hline (67) Hoşgeldin be! Davayı kazandık! & (67) Hoşgeldin! Davayı kazandık! \\
\hline
\end{tabular}

\section{Sözdizim düzeyinde değiștirim}

Durmuş (2013a: 402), metin değiştirim sürecini incelediği çalışmasında sözdizimsel düzeyde yapılabilecek değiş̧irim işlemlerine devrik cümleleri kurallı hâle getirme, zamirleri açık isimli göndermelere çevirme, uzun ve karmaşık cümleleri bölme, uzun tasvir ifadelerini kısaltma, eksiltili cümleleri tamamlamayı, 
artgönderimsel ve öngönderimsel ifadeleri belirtik duruma getirmeyi önermektedir. Benzer şekilde, Özmen (2019: 140) daha sade bir metin için zamansal ilişkilerin standart duruma getirilmesini bir sadeleştirme işlemi olarak sunmaktadır. $\mathrm{Bu}$ öneriler çerçevesinde "Rüşvet" adlı hikâyede sözdizimsel düzeyde yapılan değişimler aşağıda gösterilmiştir. İlk olarak, zamir artgönderimleri daha belirtik cümlelere çevrilmeye çalışılmıştır (Tablo 6'ya bakınız).

Tablo 6. Zamir Artgönderimlerinin Açık Isim Göndermelerine Dönüşürülmesi

\begin{tabular}{|c|c|c|}
\hline Özgün Metin & Değiştirilmiş Metin & $\begin{array}{c}\text { Yapılan } \\
\text { Değiştirim İşlemi }\end{array}$ \\
\hline $\begin{array}{l}\text { (21) Hasmı, köyün muhtarı } \\
\text { Huysuzoğlu'ydu. (22) Ona } \\
\text { ait bir arsanın üzerine Ali } \\
\text { Hoca vaktiyle bir bina yap- } \\
\text { tırmıştı. (23) Şimdi o, neden } \\
\text { sonra bu binayı kabullenme- } \\
\text { ye kalkıyordu. }\end{array}$ & $\begin{array}{l}\text { (21) Düşmanı, } \\
\text { köyün muhtarı } \\
\text { Huysuzoğlu'ydu. (22) } \\
\text { Huysuzoğlu'na ait bir } \\
\text { arsanın üzerine Ali Hoca } \\
\text { bir bina yaptırmıştı. (23) } \\
\text { Şimdi Huysuzoğlu, arsa } \\
\text { onun diye bu binayı sa- } \\
\text { hiplenmek istiyordu. }\end{array}$ & $\begin{array}{l}\text { Zamir artgönderi- } \\
\text { mi belirtik hâle ge- } \\
\text { tirilmiştir. (Diğer } \\
\text { değişiklilker yu- } \\
\text { karıda daha önce } \\
\text { gösterilmiştir) }\end{array}$ \\
\hline $\begin{array}{l}\text { (38) Namık Efendi haksız } \\
\text { davaları alamazdı. (39) Ali } \\
\text { Hoca'nın vekâlet teklifini } \\
\text { reddetmek istiyordu. (40) } \\
\text { Fakat, "Bozoyük" köyünün } \\
\text { halkı otuz senelik müşterile- } \\
\text { riydi. (41) Eşek, ahırını beller } \\
\text { gibi onun dükkânını belle- } \\
\text { mişler, hükümetteki her işleri } \\
\text { için ona müracaatı âdet edin- } \\
\text { mişlerdi. (42) Kışlık zahîresi } \\
\text { de hemen hemen tamamıyla } \\
\text { oradan gelirdi. }\end{array}$ & $\begin{array}{l}\text { (38) Namık Efendi hak- } \\
\text { sız davaları alamazdı. } \\
\text { (39) Ali Hoca'nın vekâlet } \\
\text { teklifini reddetmek } \\
\text { istiyordu. (40) Fakat, } \\
\text { "Bozoyük” köyünün } \\
\text { halkı otuz senelik müş- } \\
\text { terileriydi. (41) Eşek, } \\
\text { ahırını beller gibi Namık } \\
\text { Efendi’nin dükkânını } \\
\text { bellemişler, hükümetteki } \\
\text { her işleri için ona müra- } \\
\text { caatı âdet edinmişlerdi. } \\
\text { (42) Kışlık zahîresi de } \\
\text { hemen hemen tamamıyla } \\
\text { Bozoyük'ten gelirdi. }\end{array}$ & $\begin{array}{l}\text { Namık efendiye } \\
\text { artgönderim yapan } \\
\text { "ona" ve köye art- } \\
\text { dgönderim yapan } \\
\text { "oradan" zamirleri } \\
\text { belirtik hâle geti- } \\
\text { rilmiştir. }\end{array}$ \\
\hline
\end{tabular}

Bunu takiben eksiltili ifadelerin bir kısmı tamamlanarak daha açık yapılmaya çalışılmıştır. Bu bağlamda yapılan değişimler Tablo 7'de gösterilmiştir. 
Tablo 7. Eksiltilerin Tamamlanması

\begin{tabular}{|c|c|c|}
\hline Özgün Metin & Değiştirilmiş Metin & Yapılan Değiştirim İşlemi \\
\hline $\begin{array}{l}\text { (30) Hayır, ben haklı- } \\
\text { yım. (31) Neye binayı } \\
\text { yaparken sesini çıar- } \\
\text { mamış? }\end{array}$ & $\begin{array}{l}\text { (30) Hayır, ben haklıyım. } \\
\text { (31) Niye Huysuzoğlu } \\
\text { binayı yaparken itiraz } \\
\text { etmemiş? }\end{array}$ & $\begin{array}{l}\text { (31) numaralı cümlede kast } \\
\text { edilen kişi olan "Huysuzoğ- } \\
\text { lu" eklenerek cümle tamam- } \\
\text { lanmıştır. }\end{array}$ \\
\hline $\begin{array}{l}\text {-- (34) Davadan vaz- } \\
\text { geçmem. } \\
\text {--(35) Kaybedeceksin!.. }\end{array}$ & $\begin{array}{l}\text {-- (34) Davadan vazgeç- } \\
\text { mem. } \\
\text {--(35) Davayı kaybede- } \\
\text { ceksin!.. }\end{array}$ & $\begin{array}{l}\text { "davayı" eklenerek eksilti } \\
\text { tamamlanmıştır. }\end{array}$ \\
\hline $\begin{array}{l}\text { - (74) Evet, ama sen } \\
\text { bana "Rüşvet düşmanı- } \\
\text { dır, kim hediye verirse } \\
\text { haksız çıkar" dememiş } \\
\text { miydin? }\end{array}$ & $\begin{array}{l}\text { - (74) Evet, ama sen } \\
\text { bana hâkim "Rüşvet düş- } \\
\text { manıdır, kim ona hediye } \\
\text { verirse haksız çıkar" de- } \\
\text { memiş miydin? }\end{array}$ & $\begin{array}{l}\text { "hâkim" ve "ona" eklenerek } \\
\text { eksilti tamamlanmış, sözü } \\
\text { geçen kişinin hâkim olduğu } \\
\text { daha açı hâle gelmiştir. }\end{array}$ \\
\hline
\end{tabular}

Daha sonra, metinde bulunan "böyle" ile yapılmıș iki değiștirimli cümle incelenmiş, ilki değiştirilmezken ikincisi aşağıdaki gibi değiştirilmiştir (Tablo 8'e bakınız).

Tablo 8. Değiştirimin Belirtik Yapılması

\begin{tabular}{|c|c|c|}
\hline Özgün Metin & Değiştirilmiş Metin & Yapılan Değiştirim İşlemi \\
\hline $\begin{array}{l}\text { (57) Ali Hoca: } \\
\text { — Allah böyle doğruları } \\
\text { dünya yüzünden eksik } \\
\text { etmesin! } \\
\text { diye dua etti. }\end{array}$ & $\begin{array}{l}\text { (57) Ali Hoca: } \\
\text { - Allah bu hâkim } \\
\text { gibi dürüst insanları } \\
\text { dünyadan eksik etmesin! } \\
\text { diye dua etti. }\end{array}$ & $\begin{array}{l}\text { "böyle" kelimesiyle yapılan } \\
\text { değiştirimli ifade "hâkime" } \\
\text { işaret ettiği için "hâkim"ve } \\
\text { buna bağlı olarak "gibi" } \\
\text { edatı eklenerek belirtik hâle } \\
\text { getirilmiştir. }\end{array}$ \\
\hline
\end{tabular}

Uzun ya da karmaşık cümlelerin bölünmesi metin değiştiriminde yapılabilecek bir başka işlemdir. "Rüşvet" adlı hikâye incelendiğinde yalnızca birkaç tane uzun cümle olduğu görülmüştür. Bunların içinden anlamı sadeleştirmek adına değiştirilmesi gerektiği düşünülenler aşağıda yapılan işlemlerle sunulmuştur. 
Tablo 9. Uzun Ve/Veya Karmaşık Cümlelerin Bölünmesi

\begin{tabular}{|c|c|}
\hline Özgün Metin & Değiștirilmiş Metin \\
\hline $\begin{array}{l}\text { (4) Sonra gitti, açık kapıyı iterken } \\
\text { heybesi omuzunda, semerli atının } \\
\text { yuları elinde, sarıklı, kısa boylu } \\
\text { yuvarlak bir köylünün yaklaştığını } \\
\text { gördü. }\end{array}$ & $\begin{array}{l}\text { (4) Sonra gitti. (5) Açık kapıyı iterken, bir } \\
\text { köylünün dükkâna geldiğini gördü. (6) Köy- } \\
\text { lünün çantası omzunda idi. (7) Semerli atının } \\
\text { yuları elinde idi. (8) Köylü, sarıklı, kısa } \\
\text { boylu ve kiloluydu. }\end{array}$ \\
\hline $\begin{array}{l}\text { (41) Eşek, ahırını beller gibi onun } \\
\text { dükkânını bellemişler, hükümetteki } \\
\text { her işleri için ona müracaatı âdet } \\
\text { edinmişlerdi. }\end{array}$ & $\begin{array}{l}\text { (41) Eşek, ahırını öğrendiği gibi onun } \\
\text { dükkânını ögrenmişlerdi. (42) Hükümetteki } \\
\text { her işleri için ona müracaatı alışkanlık hâline } \\
\text { getirmişlerdi. }\end{array}$ \\
\hline $\begin{array}{l}\text { (82) Meydandaki büyük çınar } \\
\text { ağaçlarının derin fısıltıları, kapıda } \\
\text { ayakta duran Ali Hoca'nın yanla- } \\
\text { rından, tepesinden, bacaklarının } \\
\text { arasından giriyor, duvarlarına eski } \\
\text { vilayet gazeteleri yapıştırılmış } \\
\text { dükkâncığın içini dolduruyordu... }\end{array}$ & $\begin{array}{l}\text { (82) Meydandaki büyük çınar ağaçlarının } \\
\text { rüzgârda çıkardığı sesler, kapıda ayakta } \\
\text { duran Ali Hoca'nın yanlarından, tepesin- } \\
\text { den, bacaklarının arasından giriyordu. (83) } \\
\text { Duvarlarına eski il gazeteleri yapıştırılmış } \\
\text { dükkâncığın içini dolduruyordu... }\end{array}$ \\
\hline
\end{tabular}

Hikâyenin çözümlemesi sonucu elde edilen dilbilgisel eylem zamanlarının görünümüne bakıldığında bir zaman çekiminin B1 düzeyine uygun olmadığı görülmüş ve değiştirilmiştir. Bir başka cümledeki dilbilgisel zaman da öğretilmesi hedeflenen "diye" edatını da kullanarak çıkarımı daha belirtik yapmak için yeniden yapılandırılmıştır.

Tablo 10. Dilbilgisel Eylem Zamanlarının Değiştirimi

\begin{tabular}{|c|c|c|}
\hline Özgün Metin & Değiştirilmiş Metin & Yapılan Değiştirim İşlemi \\
\hline $\begin{array}{l}\text { (38) Namık Efendi hak- } \\
\text { s1z davaları alamazdı. }\end{array}$ & $\begin{array}{l}\text { (38) Namık Efendi hak- } \\
\text { sız davaları almazdı. }\end{array}$ & $\begin{array}{l}\text { Yeterlilik kipinin olumsuz } \\
\text { hikâyesi C1 düzeyinde öğ- } \\
\text { retildiği için bu çalışmanın } \\
\text { hedef grubu olan B1 düzey } \\
\text { öğrenciler bu cümleyi an- } \\
\text { lamayabilir. Bu nedenle } \\
\text { "alamazdı" geniş zamanın } \\
\text { hikâyesiyle çekimlenerek } \\
\text { "almazdı" olarak B1 düzeyine } \\
\text { uygun şekilde değiştirilmiştir. }\end{array}$ \\
\hline
\end{tabular}


(42) Kışlık zahîresi de hemen hemen tamamiyla oradan gelirdi. Nihayet:

— (43) Pekâlâ, senin bu işine bakayım. (44) Kaybedince bana darılmayacaksın! dedi.
(42) Kışlık tahılı da çoğunlukla Bozoyük'ten geliyor diye sonunda davayı almayı kabul etti.

— (43) Pekâlâ, senin bu işine bakayım. (44) Kaybedince bana darılmayacaksın! dedi.
Bu üç cümleye bakıldığında avukatın tahıllarının gelmesini de içeren bir takım faydalardan dolayı davayı kabul ettiği çıkarımı yapılabilir. Geniş zamanın hikâyesiyle çekimlenmiş olan yüklem "gelirdi”yi şimdiki zaman çekimiyle kullanarak ve öğretilmesi hedeflenen "diye"nin ve bu doğrultuda bağlaşıklığ sağlamak için "davayı almayı kabul etti" cümlesinin eklenmesiyle bu sebep-sonuç ilişkisi daha belirtik hâle gelmiştir.

Bu işlemler sonucu değiştirilen metnin tam hâli (Ek 2'ye bakınız) ekler bölümünde sunulmuştur. Yeniden yapılandırılan metnin kelime dağılımı incelendiğinde değiştirim sonucu metnin hacminin büyüyerek 484 kelimeden 505 kelimeye çıktığı ve cümle sayısının da arttığı görülmektedir. Bu bulgular Durmuş'un da (2013a: 400) ifade ettiği gibi metin değiştirim sürecinde sadeleştirmenin zaman zaman genişletime dönüşerek metni büyüttüğünü göstermektedir.

\section{Sonuç}

Yabanc1 dil öğretiminde özgün malzeme kullanımı, yukarıda da ele alındığ 1 gibi hedef dilin kültürel ögelerini içerme, gerçek iletişim durumlarını yansıtma ve dilin doğal bağlamında kullanımını gösterme gibi faydalarından dolayı yaygınlaşmıştır. Bu faydalardan dolayı yabancı dil öğretiminde özgün metnin kullanımı savunulsa da bu metinlerin, öğrencilerin düzeyine uymadığ 1 zamanlarda dilsel girdiyi öğrenciye iletmekte başarısız olduğu ve metnin anlaş1lırlığının kaybolduğu durumlar olmaktadır. Bunun önüne geçmek ve mümkün olduğunca öğrencileri özgün içeriğe maruz bırakmak için değiştirim işlemleri yapılmaktadır. Değiştirim için yapılandırma işlemleri kadar seçilen metin de önemlidir ve anlatı metinlerinin yabancı dil öğretiminde değiştirilebilecek en uygun metin türlerinden olduğu ileri sürülebilir. Bu süreçte, metin seçiminde dilbilgisel, konu- 
sal ve işlenebilirlik açısından yukarda ele alınan söz varlığı ve sözdizimsel olarak öğrencilerin dil düzeyine uygunluk, evrensel temalar içeren ve derste kullanmaya uygun uzunlukta olması gibi ölçütlere dikkat edilmesi gerekmektedir. Bu ölçütlere dayanan metin seçimi ve metnin yapısal özelliklerinin çözümlemesiyle hedef düzeye uygun bir değiştirim işleminin gerçekleşebileceği ve özgün metnin yapısı bozulmadan derste kullanılabileceği düşünülmektedir. Bu çalışmada, söz konusu ilkelere dayanarak "Rüşvet" adlı hikâye B1 düzeyine göre değiştirilmiş, öğrenicilerin mevcut düzeyinin bir adım ötesindeki öğretilmesi hedeflenen yapı (i+1) olarak özgün metindeki "nedenleştirme "diye" edatı korunmuştur. Söz konusu metin uyarlama işleminin yabancı dil olarak Türkçe öğretiminde hikâye gibi anlatı metinlerinin öğrenici düzeyine göre değiştirilerek kullanılmasına örnek oluşturabileceği düşünülmektedir. 


\section{Kaynakça}

Al Azri, Rashid Hamed ve Al-Rashdi, Majid Hilal (2014). "The effect of using authentic materials in teaching”. Internatıonal Journal of Sclentıfic \& Technology Research 3 (10): 249-254.

Aziz, Anealka, Chan Yuen Fook ve Zubaidah, Alsree (2010). "Scientific Structural Changes within Texts of Adapted Reading Materials". English Language Teaching 3 (4): 216-223.

Bakan, Hande (2012). Yabancılara Türkçe Öğretiminde Metin Dilbilimsel Ölçütler Çerçevesinde Bir Sadeleştirme Denemesi: Sait Faik Abastyanık, Meserret Oteli. Ankara: Ankara Üniversitesi Sosyal Bilimler Enstitüsü, Yayımlanmamış Yüksek Lisans Tezi.

Bakır, Sinan (2015). “Orhan Kemal'in Hikâyelerinde Anlatıcı ve Bakış Açısı”. Türkiyat Mecmuas1 25: 31-60.

Brown, Penelope ve Levinson, Stephen C. (1987). Politeness: Some universals in language usage. Cambridge: Cambridge University Press.

Crossley, Scott A. (2018). Authentic and simplified texts. J. I. Liontas ve M. DelliCarpini (Ed) The TESOL Encyclopedia of English Language Teaching içinde (s. 1-7).

Crossley, Scott A., David B. Allen ve Danielle S. Mcnamara (2011). "Text Readability and Intuitive Simplification: A Comparison of Readability Formulas". Reading in a Foreign Language 23 (1): 84-102.

Dilidüzgün, Şükran (2008). Türkçe Öğretiminde Metindilbilimsel Bağlamda Uygulamalı Bir Yaklaşım. (Yayımlanmış Doktora Tezi). İstanbul: İstanbul Üniversitesi Sosyal Bilimler Enstitüsü.

Durmuş, Mustafa (2013a). "Metin Değiştirimin Dilbilimsel Süreçleri Üzerine”. International Journal of Social Science 6 (4): 391-408.

Durmuş, Mustafa (2013b). "İkinci/Yabanc1 Dil Öğretiminde Sadeleştirilmiş Metin Sorunları Üzerine”. Bilig 65: 135-150.

Durmuş, Mustafa (2019). Kültürel içeriklerin belirlenmesi ve sunumunda yeterlilik. Dil öğretiminde ögretici yeterlilikleri ve pedagojik muhakeme becerisi içinde (s. 51-74). Ankara: Grafiker Yayınları.

Eziler Kıran, Ayşe (2015). Anlambilim ve dil öğretimi. Ece Korkut ve İrem Onursal Ayırır (Ed.), Dil Bilimleri ve Dil Öğretimi içinde (s. 63-101). Ankara: Seçkin.

Harmer. Jeremy (1991). The practice of English language teaching. London: Longman Group UK Limited.

Korkut, Ece (2015). Metin dilbilimi ve dil öğretimi. Ece Korkut ve İrem Onursal Ayırır (Ed.), Dil Bilimleri ve Dil Öğretimi içinde (s. 159-188). Ankara: Seçkin.

Kramsch, Claire (2013). "Culture in Foreign Language Teaching”. Iranian Journal of Language Teaching Research 1 (1): 57-78. 
Krashen, Stephen (1982). Principles and Practice in Second Language Acquisition. Oxford: Pergamon.

Labov, William (1972). The transformation of experience in narrative syntax. William Labov (haz) içinde Language in the Inner City: Studies in the Black English Vernacular, ss. 354-396.

Oh, Sun-Young (2001). "Two Types of Input Modification and EFL Reading Comprehension: Simplification versus Elaboration”. Tesol Quarterly 35 (1): 69-96.

Özmen, Ceren (2019). Yabancı Dil Olarak Türkçe Öğretiminde Metin Değiştirim Teknikleriyle Hikâyelerin Yeniden Oluşturulması. Hacettepe Üniversitesi, Türkiyat Araştırmaları Enstitüsü Yayınlanmamış Doktora Tezi, Ankara.

Ros i Solé, Cristina (2007). "Language Learners' Sociocultural Positions in The L2: A Narrative Approach". Language and Intercultural Communication 7 (3): 203-216.

Safari, Mahmood ve Montazeri, Mana Mohaghegh (2017). “The Effect of Reducing Lexical and Syntactic Complexity of Texts on Reading Comprehension". Journal of Teaching Language Skills 36 (3): 59-83.

Searle, John. R. (1979). Expression and Meaning: Studies in The Theory of Speech Acts. Cambridge: Cambridge University Press.

Seyfettin, Ömer. Ömer Seyfettin Türk Klasikleri Seçme Hikâyeler MEB Yayınları S: 151

Taşıgüzel, Selver (2004). “İlköğretim Türkçe Ders Kitaplarında Öğretici Nitelikli Metinlerdeki Eşdizimsel Örüntülemelerin Görünümleri”. https://dspace.ankara.edu.tr/xmlui/handle/123456789/62464 (Erişim Tarihi: 08.01.2020) 72-87.

Ülper, Hakan (2010). Okuma Anlamlandırma Sürecini Etkileyen Metinsel Etmenler, Okuma ve Anlamlandırma Becerilerinin Kazandırılması içinde, Anlara: Nobel Yayıncılık, s. 100-117.

Wardhaugh, Ronald ve Janet M. Fuller (2015). An introduction to sociolinguistics. West Sussex: Blackwell Publishing.

Yano, Yasukata, Michael H. Long ve Steven Ross (1994). "The Effects of Simplified and Elaborated Texts on Foreign Language Reading Comprehension”. Language Learning 44: 189-219.

Yazıcı, Nermin (2013). "Deli Dumrul'da Anlatının Düzenlenişi ve Retorik Şemanın Görünümü”. Milli Folklor 25 (98): 87-99.

Yazıcı, Nermin (2017). "Kurmaca Anlatılarda Kahramanın Sunumu: Metinleştirme Stratejisi Olarak Gönderim Ve Eksiltme”. Türkbilig 34: 117-134.

Yemenici, Alev (1996). "Söylem Çözümlemesi: Türk, İngiliz ve Amerikan Kültürlerinde Anlatılan Hikâyelerin Kültürel Bir Çerçeve İçinde İncelenmesi”. Dilbilim Araştırmaları 37-57.

Yule, George (1996). Pragmatics. Oxford, UK: Oxford University Press. 


\section{Ekler}

\section{Ek 1: Özgün metin}

\section{RÜŞVET \\ Ömer Seyfettin}

Çarşı meydanının büyük çınar ağaçları, yere düşen gölgelerini alacalandırarak, fısıldıyorlardı. Kuvvetli bir rüzgâr esiyordu. Avukat Hacı Namık Efendi, kâğıtlarım uçmasın diye zümrüt bir kameriyeye benzeyen küçük dükkânının camlarını indirdi. Sonra gitti, açık kapıyı iterken heybesi omuzunda, semerli atının yuları elinde, sarıklı, kısa boylu yuvarlak bir köylünün yaklaştığını gördü:

— Merhaba Ali Hoca, dedi, böyle vakitsiz ne arıyorsun burada? Daha pazara iki gün var...

Köylü, siyah sivri iki noktaya benzeyen mini mini gözlerini daha fazla küçülterek:

— Aleyküm selam, Namık Efendi! Belaya düştüm. Bir dava için geliyorum...

diye başını salladı.

— Ey, gel, biraz konuşalım bakalım.

- Konuşalım.

- Derdini anlat bana bakayım.

- Senden başka zaten kime anlatacağım?

Atının yularını peykenin destek direğine bağladı. Küçük dükkâna girdi. Ceviz yazıhanenin sağındaki hasırlı alçak sedire oturdu. Heybesini yanına koydu. Namık Efendi'nin uzattığı tabakadan sigara sararken davasını anlattı. Hasmı, köyün muhtarı Huysuzoğlu'ydu. Ona ait bir arsanın üzerine Ali Hoca vaktiyle bir bina yaptırmıştı. Şimdi o, neden sonra bu binayı kabullenmeye kalkıyordu. Hâlbuki bina kimin ise yerde onun demekti...

Namık Efendi kır sakalını kaşıdı. Gözlügünün üstünden bakarak:

— Sen haksızsın Ali Hoca! dedi.

- Haksız miyım?

- Evet.

- Hayır, ben haklıyım. Neye binayı yaparken sesini çıkarmamış?

- Çıkarmasın.

— Ben haklı olduğumu biliyorum, Namık Efendi. Davadan vazgeçmem.

— Kaybedeceksin!

— Edeyim, zararı yok. Ama davadan vazgeçmem.

Namık Efendi haksız davaları alamazdı. Ali Hoca'nın vekâlet teklifini reddetmek istiyordu. Fakat "Bozoyük" köyünün halkı otuz senelik müşterileriydi. Eşek ahırını beller gibi 
onun dükkânını bellemişler, hükümetteki her işleri için ona müracaatı âdet edinmişlerdi. Kışlık zahîresi de hemen hemen tamamiyla oradan gelirdi. Nihayet:

— Pekâlâ, senin bu işine bakayım. Kaybedince bana darılmayacaksın! dedi.

— Darılmam, ama neye kaybedeceksin?

— Çünkü haksızsın.

— Hâkime güzel bir koç göndersem?..

$-\mathrm{Ne}$ ?.

- O vakit davayı kazanamaz miyım?

— O vakit hiç şüphesiz kaybedersin işte!..

- Niçin?

— Yeni hâkim senin bildiğin adamlardan değil...

$-\ldots$

Ali Hoca avukatının heyecanını anlayamıyordu. Ondan yeni hâkimin methini uzun uzadıya dinledi. Bu zat rüşvetin, hediyenin korkunç bir düşmanıymış! En haklı bir davacı kendisine rüşvet vermeye teşebbüs etse o saatte onu haksız çıkarırmış! Ali Hoca:

— Allah böyle doğruları dünya yüzünden eksik etmesin!

diye dua etti. Namık Efendi:

— Âmin, âmin! dedi.

Davaya, doğruluğa dair bir saat kadar konuştular. Vekâlet için anlaştılar. Avukat ümitsizdi. Bu işi hatır için alıyordu. Haksızlık o kadar meydanda idi ki...

İki hafta sonra, aynı saatte Ali Hoca, yeşil boyalı dükkânın kapısında göründü. Namık Efendi bir arzuhâl yazıyordu. Gözlüğünün üstünden müşterisini görünce güldü:

— Hoşgeldin be! Ne dersin, davayı kazandık!

Dedi. Bu kadar haksız bir hükmü hâkimin nasıl verdiğine bir haftadır şaşıyordu. Ali Hoca soğukkanlı:

— Benim gönderdiğim koç sayesinde kazandık! cevabını verdi.

— Ne!.. Sen hâkime bir koç mu gönderdin?

- Evet.

- Buna cesaret ettin ha...

— Evet, ama sen bana "Rüşvet düşmanıdır, kim hediye verirse haksız çıkar" dememiş miydin?

- Evet.

— Ben de koçu gönderirken kendi ismimi vermedim.

- Ya ne yaptın?

— Hasmım, muhtar Huysuzoğlu'nun ismini verdim.

$-! ! ! \ldots$ 

244 Şeyma KÖKCÜ, Yabancı Dil Olarak Türkçe Öğretiminde Metin Değiştirimine Ömer Seyfettin'in

İhtiyar avukatın kalem elinden düştü. Arkasına dayandı. Karşısında parlayan mini mini siyah gözlere bakakaldı. Meydandaki büyük çınar ağaçlarının derin fısıltıları, kapıda ayakta duran Ali Hoca`nın yanlarından, tepesinden, bacaklarının arasından giriyor, duvarlarına eski vilayet gazeteleri yapıştırılmış dükkâncı̆̆ın içini dolduruyordu... 


\section{Ek 2:}

\section{Değiştirilmiş metin}

\section{RÜŞVET}

Ömer Seyfettin

Çarşı meydanındaki büyük çınar ağaçlarının gölgeleri rüzgârla hareket ediyordu. Kuvvetli bir rüzgâr esiyordu. Avukat Hacı Namık Efendi, kâğıtları uçmasın diye yeşil bir çardağa benzeyen küçük dükkânının camlarını indirdi. Sonra gitti. Açık kapıyı iterken bir köylünün dükkâna geldiğini gördü. Köylünün çantası omzunda idi. Semerli atının yuları elinde idi. Köylü, sarıklı, kısa boylu ve kiloluydu. Namık Efendi:

— Merhaba Ali Hoca, dedi, böyle uygun olmayan bir zamanda ne arıyorsun burada? Daha pazara iki gün var...

Köylü, siyah sivri iki noktaya benzeyen mini mini gözlerini daha fazla küçülterek:

— Aleyküm selam, Namık Efendi! Bir bela var. Bir dava için geliyorum...diye başını salladi.

— Tamam, gel, biraz konuşalım bakalım.

- Konuşalım.

- Derdini anlat bana bakayım.

— Senden başka zaten kime anlatacağım?

Atının yularını tahta sedirin destek direğine bağladı. Küçük dükkâna girdi. Ceviz yazıhanenin sağındaki hasırlı alçak sedire oturdu. Çantasını yanına koydu. Namık Efendi'nin uzattığı sigara kutusundan sigara sararken davasını anlattı. Düşmanı, köyün muhtarı Huysuzoğlu’ydu. Huysuzoğlu'na ait bir arsanın üzerine Ali Hoca bir bina yaptırmıştı. Şimdi Huysuzoğlu, arsa kendisinin diye bu binayı sahiplenmek istiyordu. Hâlbuki bina kimin ise yer de onun demekti...

Namık Efendi kır sakalını kaşıdı. Gözlüğünün üstünden bakarak:

- Sen haksızsin Ali Hoca! dedi.

- Haksız miyım?

- Evet.

— Hayır, ben haklıyım. Niye Huysuzoğlu binayı yaparken itiraz etmemiş?

- Etmesin.

— Ben haklı olduğumu biliyorum, Namık Efendi. Davadan vazgeçmem.

- Davayı kaybedeceksin!

— Edeyim, zararı yok. Ama davadan vazgeçmem.

Namık Efendi haksız davaları almazdı. Ali Hoca'nın vekâlet teklifini reddetmek istiyordu. Fakat "Bozoyük" köyünün halkı otuz senelik müşterileriydi. Eşek ahırını öğrendiği gibi onun dükkânını öğrenmişlerdi. Hükümetteki her işleri için ona müracaatı alışkanlık hâline getirmişlerdi. Kışlık tahılı da çoğunlukla Bozoyük’ten geliyor diye sonunda davayı almayı kabul etti. 
— Pekâlâ, senin bu işine bakayım. Kaybedince bana darılmayacaksın! dedi.

— Darılmam, ama niye kaybedeceksin?

— Çünkü haksızsın.

— Hâkime güzel bir koç göndersem?.

$-\mathrm{Ne}$ ?.

- O vakit davayı kazanamaz mıyım?

- $\mathrm{O}$ vakit hiç şüphesiz kaybedersin işte!..

- Niçin?

— Yeni hâkim senin bildiğin adamlardan değil...

- ....

Ali Hoca avukatının heyecanını anlayamıyordu. Ondan yeni hâkimin övülmesini uzun uzun dinledi. Bu kişi rüşvetin, hediyenin korkunç bir düşmanıymış! En haklı bir davacı kendisine rüşvet vermeyi denese onu haksız çıkarırmış. Ali Hoca:

— Allah bu hâkim gibi dürüst insanları dünyadan eksik etmesin! diye dua etti. Namık Efendi:

- Âmin, âmin! dedi.

Davaya, doğruluğa dair bir saat kadar konuştular. Vekâlet için anlaştılar. Avukat ümitsizdi. Bu işi hatır için alıyordu. Haksızlık o kadar meydanda idi ki...

İki hafta sonra, aynı saatte Ali Hoca, yeşil boyalı dükkânın kapısında göründü. Namık Efendi bir dilekçe yazıyordu. Gözlüğünün üstünden müşterisini görünce güldü:

— Hoşgeldin! Davayı kazandık! dedi. Bu kadar haksız bir kararı hâkimin nasıl verdiğine bir haftadır şaşıyordu. Ali Hoca soğukkanlı:

— Benim gönderdiğim koç sayesinde kazandık! cevabını verdi.

— Ne!.. Sen hâkime bir koç mu gönderdin?

- Evet.

- Buna cesaret ettin ha...

— Evet ettim. Ama sen bana hâkim "Rüşvet düşmanıdır, kim ona hediye verirse haksız çıkar" dememiş miydin?

- Evet.

— Ben de koçu gönderirken kendi ismimi vermedim.

- Ya ne yaptın?

— Düşmanım, muhtar Huysuzoğlu'nun ismini verdim.

- !!!...

İhtiyar avukatın kalem elinden düştü. Arkasına dayandı. Karşısında parlayan mini mini siyah gözlere bakakaldı. Meydandaki büyük çınar ağaçlarının rüzgârda çıkardığı sesler, kapıda ayakta duran Ali Hoca'nın yanlarından, tepesinden, bacaklarının arasından giriyordu. Duvarlarına eski şehir gazeteleri yapıştırılmış dükkâncığın içini dolduruyordu... 